\title{
ANALISIS KADAR KARBON DIOKSIDA DI SUNGAI AMPENAN LOMBOK
}

\section{CARBON DIOXIDE CONCENTRATION ANALYSIS AT AMPENAN RIVER LOMBOK}

\author{
Syarifa Wahidah Al Idrus \\ Program studi pendidikan kimia, Jurusan PMIPA Universitas Mataram \\ Jalan Majapahit No 62 Mataram 83125, telp 0370-623873, fax 0370-634918 \\ Email : syarifaidrus@,unram.ac.id
}

Diterima: 25 Juli 2018. Disetujui: 14 September 2018. Dipublikasikan: 27 September 2018

\begin{abstract}
Abstrak. Telah dilakukan penelitian tentang analisis kadar $\mathrm{CO}_{2}$ pada sungai Ampenan di Kota Mataram, Lombok, Indonesia. Tujuan dari penelitian ini untuk mengetahui kadar karbondioksida dalam air sungai. Penelitian ini dilakukan dengan mengambil sampel air pada 5 titik sampel pada sungai Ampenan dan satu kontrol yang diambil dari air yang secara fisik tidak mengalami pencemaran. Hasil pengamatan yang dilakukan secara fisik, sungai Ampenan mengalami pencemaran dari segi bau, warna dan suhu. Berdasarkan hasil analisis kadar $\mathrm{CO}_{2}$ diperoleh hasil pada kelima titik sampel adalah 50, 30, 15 dan $10 \mathrm{mg} / \mathrm{l}$ Kadar $\mathrm{CO}_{2}$ pada sungai Ampenan berada dalam kategori tinggi di atas ambang batas 5-10 mg/l. Kadar karbondioksida pada sungai Ampenan tergolong tinggi karena masyarakat sekitar membuang sampah langsung ke sungai. Solusi untuk mengatasi tingginya karbondioksida adalah melakukan aerasi atau melakukan pengaturan sirkulasi air. Sirkulasi air bisa berjalan dengan baik dengan cara mengurangi sampah disekitar daerah aliran sungai Ampenan, dan diberikan sanksi tegas pada masyarakat yang membuang sampah/limbah ke aliran sungai.
\end{abstract}

Kata kunci: analisis kadar $\mathrm{CO}_{2}$, sungai Ampenan, Lombok

\begin{abstract}
Research has been carried out on the analysis of CO2 levels in the Ampenan river in Mataram City, Lombok, Indonesia. The purpose of this study is to determine the level of carbon dioxide in the river. This research was conducted by taking water samples at 5 sample points on the Ampenan river and one control sample that was physically not contaminated. Physically observed, the Ampenan river experienced pollution in terms of odor, color and temperature. Based on the results of the analysis of $\mathrm{CO} 2$ levels the results of the five sample points were 50,30,15 and $10 \mathrm{mg} / 1$. The CO2 concentration in the Ampenan river is above the 5-10 $\mathrm{mg} / \mathrm{l}$ threshold. Dissolved carbon dioxide in the Ampenan river is high because people around throw garbage directly into the river. The solution to overcome the high dissolved carbon dioxide is to do aeration or regulation of water circulation. Waste in the Ampenan river must be reduced so that water circulation can run well. Strict sanctions on people who throw garbage into the river stream need to be applied.
\end{abstract}

Keywords: $\mathrm{CO}_{2}$ level analysis, Ampenan river, Ampenan, Lombok

\section{PENDAHULUAN}

Air merupakan sumber kehidupan, tidak hanya bagi manusia, makhluk hidup yang lain juga sangat membutuhkan air. kekurangan air pada tubuh manusia biasa menyebabkan dehidrasi karena ketahanan tubuh manusia sangat bergantung pada berbagai fungsi air, sedangkan tubuh manusia belum mengembangkan suatu sistem penyimpanan air sebagai sistem penyimpanan lemak. Ketersediaan air dari segi kualitas maupun kuantitas mutlak diperlukan. Air di Indonesia sangat melimpah karena Indonesia merupakan Negara kepulauan. Akan tetapi, hal ini tidak dimanfaatkan dengan baik oleh masyarakat Indonesia. Sebaliknya, masyarakat kebanyakan menyalahgunakan kelebihan ini dengan mencemarinya [1-3].

Pencemaran air yaitu masuknya mahluk hidup, zat, energi atau komponen lain ke dalam air, sehingga kualitas air turun sampai ketingkat tertentu yang menyebabkan air tidak berfungsi lagi sesuai dengan peruntukannya. Air tersebut juga mempunyai standar 3B (tidak berwarna, berbau, dan beracun). Air merupakan suatu zat pelarut yang sangat berguna bagi semua mahluk hidup. Dalam air terkandung berbagai macam unsur-unsur yang membentuk suatu unit yang saling berkaitan dan sangat berpengaruh terhadap sifat dan kualitas air itu sendiri. Air merupakan bahan yang amat penting (essensial) bagi kehidupan organism [4-6].

Salah satu parameter kimia yang ada di dalam perairan yaitu gas karbondioksida $\left(\mathrm{CO}_{2}\right)$ yang dipengaruhi kualitas air. Ketersediaan gas ini dalam perairan jumlahnya lebih sehingga akan mempengaruhi organisme-organisme yang melakukan proses respirasi sedangkan kekurangan gas ini akan mempengaruhi organisme dalam proses fotosintesis. Karbondioksida $\left(\mathrm{CO}_{2}\right)$ tidak bertambah banyak pada kedalaman yang lebih 
besar kecuali di lapisan dekat dengan dasar, demikian pula dengan $\mathrm{pH}$. Karena Kalsium karbonat yang diendapkan di daerah trophogenic jatuh perlahan-lahan ke dasar dan bertemu dengan karbondioksida $\left(\mathrm{CO}_{2}\right)$ agresif didaerah tropholytic, serta menambah kosentrasinya di lapisan bawah Karbondioksida merupakan unsur utama dalam proses fotosintesis yang dibutuhkan oleh fitoplankton dan tumbuhan air. Keberadaan karbondioksida diperairan sangat dibutukan oleh tumbuhan baik yang besar maupun yang kecil untuk proses fotosintesis [7]. $\mathrm{CO}_{2}$ juga terbentuk dalam air karena proses dekomposisi (oksidasi) zat organik oleh mikroorganisme. Umumnya juga terdapat dalam air yang telah tercemar. Karbondioksida pula diperairan berasal dari difusi atmosfer, air hujan, air yang melewati tanah organik, dan respirasi tumbuhan dan hewan, serta bakteri aerob dan anaerob [8].

Karbondioksida $\left(\mathrm{CO}_{2}\right)$ mempunyai peranan yang sangat besar bagi kehidupan organisme air. Senyawa tersebut dapat membantu dalam proses dekomposisi atau perombakan bahan organik oleh bakteri. Namun jika dalam keadaan yang berlebihan dapat mengganggu bahkan menjadi racun bagi beberapa jenis ikan [9]. Kandungan $\mathrm{CO}_{2}$ diperairan digunakan untuk melarutkan kapur, yaitu untuk mengubah senyawa menjadi kalsium bikarbonat $\mathrm{Ca}\left(\mathrm{HCO}_{3}{ }^{-}\right)$. Agar supaya bikarbonat menjadi mantap sejumlah karbondioksida $\left(\mathrm{CO}_{2}\right)$ tertentu harus tetap berada dalam larutan yang dapat memperbaiki dan mempertahankan kalsium. Kadar karbondioksida $\left(\mathrm{CO}_{2}\right)$ yang baik bagi organisme perairan yaitu kurang lebih $15 \mathrm{mg} / \mathrm{l}$. Jika lebih dari itu sangat membahayakan karena menghambat pengikatan oksigen $\left(\mathrm{O}_{2}\right)$. Lebih lanjut dikatakan kadar karbondioksida yang berlebih dapat diatasi dengan melakukan penggantian air secara rutin, mengurangi pertumbuhan ganggang yang terlalu lebat dan peningkatan peranan kincir air [10].

Karbondioksida dari udara selalu bertukar dengan karbondioksida yang ada di air. Pada air yang tenang pertukaran ini sedikit, proses yang terjadi adalah difusi. Sehingga kadar yang di perlukan pertukarannya berubah lebih cepat dan air dipermukaan berpusar menuju kebagian dasar perairan [11]. Kandungan $\mathrm{CO}_{2}$ bebas dalam air dapat didefinisikan sebagai jumlah $\mathrm{CO}_{2}$ yang larut dalam air. Kandungan $\mathrm{CO}_{2}$ dalam perairan maksimal $20 \mathrm{mg} / \mathrm{l}$. Kandungan $\mathrm{CO}_{2}$ bebas paada suatu perairan apabila melebihi $20 \mathrm{mg} / 1$ maka akan membahayakan biota laut bahkan meracuni kehidupan organisma perairan. Kandungan $\mathrm{CO}_{2}$ dalam suatu perairan apabila lebih tinggi dari 12 $\mathrm{mg} / \mathrm{l}$ dapat membahayakan kehidupan organisma perairan,dapat diassumsikan bahwa bila dalam suatu perairan kadar $\mathrm{CO}_{2}$ berlebihan dapat berdampak kritis bagi binatang air [11].

\section{METODE PENELITIAN}

Penelitian ini dilaksanakan di beberapa titik pada sungai Ampenan, dan di laboratorium kimia FKIP Universitas Mataram. Penelitian dilaksanakan pada bulan juli, metode yang digunakan adalah observasi dan eksperimen. Penentuan kadar $\mathrm{CO}_{2}$ dengan menggunakan metode titrasi.

Sampel air sungai Ampenan yang diambil pada tiga titik lokasi yang berbeda. Sebelum dilakukan analisis kadar $\mathrm{CO}_{2}$, diamati kondisi fisik air.

1. Persamaan reaksi $\mathrm{CO}_{2(\mathrm{~g})}+\mathrm{H}_{2} \mathrm{O}_{(\mathrm{l})} \longrightarrow \mathrm{H}_{2} \mathrm{CO}_{3}(\mathrm{aq})$

2. Perhitungan

Rumus menghitung kadar $\mathrm{CO}_{2}$ terlarut dalam air :

$$
\text { Kadar } \mathrm{CO} 2=\frac{1000}{\mathrm{~V}} \times \mathrm{p} \times 0,5
$$

Keterangan:

$1000=\mathrm{mL} /$ liter air; $\mathrm{P}=$ volume titran $\left(\mathrm{H}_{2} \mathrm{SO}_{4}\right)$ yang digunakan; $0,5=$ jumlah $\mathrm{mg} /$ liter setara $\mathrm{CO}_{2}$ $0,5 \mathrm{M} \mathrm{H}_{2} \mathrm{SO}_{4} ; \mathrm{v}=$ volume air yang dititrasi

\section{HASIL DAN PEMBAHASAN}

Penelitian ini bertujuan untuk mengetahui kadar karbondioksida dalam air sungai (sampel). Dimana sampel air sungai tersebut diambil di sungai Ampenan, Mataram. Sampel tersebut diambil dari 5 titik yaitu dari yang terkotor hingga yang paling bersih. Indikator yang terkotor sampai yang terbersih dilihat dari kualitas air secara fisik (warna dan bau). Sampel tersebut diberi perlakuan di laboratorium untuk dianalisis. Karbondioksida $\left(\mathrm{CO}_{2}\right)$ dari udara selalu bertukar dengan karbondioksida yang ada di air.

Pada air yang tenang pertukarannya sedikit, sehingga proses yang terjadi adalah difusi. Pada perubahan warna yang terjadi saat penelitian, karbondioksida dalam suatu perairan tidak lepas dari pengaruh parameter seperti oksigen terlarut, alkalinitas, cahaya, $\mathrm{pH}$ dan sebagainya. Semakin tinggi karbondioksida, maka oksigen yang dibutuhkan bertambah. Konsentrasi karbondioksida sangat erat pula hubungannya dengan konsentrasi oksigen terlarut dalam suatu perairan. Tingginya karbondioksida dalam perairan akan menyebabkan oksigen terlarut dalam perairan menjadi menurun sehingga akan menyebabkan kematian pada ikan,dan $\mathrm{pH}$ yang baik untuk peraiaran adalah standard pada kisaran nilai $\mathrm{pH}$ 7-8, kesalahan dari ketidakaturan pengukuran $\mathrm{pH}$ akan meningkat dengan meningkatnya nilai alkalinitas total [12]

Pada penelitian ini didapatkan hasil kadar karbondioksida dalam $\mathrm{mg} / \mathrm{l}$. Untuk titik yang pertama yaitu didapatkan $50 \mathrm{mg} / \mathrm{l}$. Hal ini menandakan bahwa pada titik ini sangat tercemar. 
Kemudian pada titik yang kedua yaitu didapatkan $30 \mathrm{mg} / \mathrm{l}$. Hal ini menandakan bahwa pada titik tersebut juga tercemar. Kemudian pada titik yang ketiga yaitu didapatkan $15 \mathrm{mg} / \mathrm{l}$. Hal ini juga menandakan bahwa pada titik ini juga tercemar. Kemudian untuk membandingkannya, kami menggunakan air yang dengan kondisik fisik lebih bersih, dimana didapatkan kadarnya sebesar 10 $\mathrm{mg} / \mathrm{l}$. Sehingga dapat dikatakan bahwa sampel yang kami gunakan telah tercemar karbondioksida. Dikatakan tercemar karena kadar karbondioksida yang didapatkan lebih dari $12 \mathrm{mg} / \mathrm{l}$.

Meskipun peranan $\mathrm{CO}_{2}$ sangat besar bagi kehidupan organisme air, namun kandungan $\mathrm{CO}_{2}$ bebas yang berlebihan sangat mengganggu, bahkan merupakan racun langsung bagi ikan. Daya toleransi ikan terhadap kandungan $\mathrm{CO}_{2}$ bebas dalam air bermacam-macam tergantung jenisnya, tetapi pada umumnya bila lebih dari $15 \mathrm{mg} / \mathrm{l}$ dapat memberikan pengaruh yang merugikan bagi ikan [12]

Perairan air tawar alami hampir tidak pernah memiliki $\mathrm{pH}>9$ sehingga tidak ditemukan karbon dalam bentuk karbonat. Pada air tanah, kadar karbondioksida biasanya sekitar 10 mg/l karena sifat air tanah cenderung alkalis. Perairan yang memiliki kadar sodium tinggi mengandung karbonat sekitar $50 \mathrm{mg} / \mathrm{l}$. Perairan tawar air yang memiliki $\mathrm{pH}$ 7-8 biasanya mengandung ion karbonat < 500mg/l dan hampir tidak pernah kurang dari $25 \mathrm{mg} / \mathrm{l}$. ion ini mendominasi sekitar $60-90 \%$ bentuk karbon anorganik total diperairan. Kadar karbon dioksida sebesar 5-10 mg/l di dalam air masih dapat di toleransi oleh hewan air asalkan kadar oksigen nya cukup tinggi. Akan tetapi kadar karbondioksida 50-100 mg/l dapat mematikan ikan dan udang dalam waktu lama [12].

Jumlah karbon dalam air sungai Ampenan, berada dalam kategori yang cukup tinggi dan sangat berbahaya bagi biota yang ada diperairan. Karena biota yang ada diperairan bisa mentoleransi kadar $\mathrm{CO}_{2}$ sebesar 5- $10 \mathrm{mg} / \mathrm{l}$. tingginya konsentrasi $\mathrm{CO}_{2}$ pada suatu perairan bisa di pengaruhi oleh parameter kualitas air yang lain seperti $\mathrm{pH}$, alkalinitas, oksigen terlarut.

Berdasarkan hasil penelitian tingginya kadar karbondioksidadi perairan sungai Ampenan menyebabkan sungai Ampenan tidak bisa berfungsi sebagaimana mestinya. Karbondioksida $\left(\mathrm{CO}_{2}\right)$ mempunyai peranan yang sangat besar bagi kehidupan organisme air. Senyawa tersebut dapat membantu dalam proses dekomposisi atau perombakan bahan organik oleh bakteri. Namun jika dalam keadaan yang berlebihan dapat mengganggu bahkan menjadi racun bagi beberapa jenis ikan $[9,15]$.

Tabel. Kadar $\mathrm{CO}_{2}$ pada sampel air sungai Ampenan

\begin{tabular}{lccc}
\hline Sampel & Volume $(\mathrm{ml})$ & Volume tiran & ${\operatorname{Kadar~} \mathrm{CO}_{2}(\mathrm{mg} / \mathrm{l})}$ \\
\hline Sampel 1 & 10 & 1 & 50 \\
Sampel 2 & 10 & 0,6 & 30 \\
Sampel 3 & 10 & 0.3 & 15 \\
kontrol & 10 & 0,2 & 10 \\
\hline
\end{tabular}

Kadar karbondioksida $\left(\mathrm{CO}_{2}\right)$ yang baik bagi organisme perairan yaitu kurang lebih 15 $\mathrm{mg} / \mathrm{l}$. Jika lebih dari itu sangat membahayakan karena menghambat pengikatan oksigen $\left(\mathrm{O}_{2}\right)$. Lebih lanjut dikatakan kadar karbondioksida yang berlebih dapat diatasi dengan melakukan penggantian air secara rutin, mengurangi pertumbuhan ganggang yang terlalu lebat dan peningkatan peranan kincir air [10].

Peningkatan kadar karbondioksida terlarut sangat mempengaruhi aktivitas organisme yang ada di dalam utamanya persaingan dalam proses respirasi. Solusi yang dapat dilakukan apabila hal tersebut terjadi yaitu dengan cara pengaturan sirkulasi air dengan teratur dan dapat pula digunakan aerator apabila kondisi perairan kecil [9]. Penanggulanganya dapat dilakukan dengan menaikkan $\mathrm{pH}$ serta dengan menambahkan senyawa kimia yang bersifat basa, pada umumnya digunakan kapur [14].
Karbondioksida $\left(\mathrm{CO}_{2}\right)$ dari udara selalu bertukar dengan karbondioksida yang ada di air. Pada air yang tenang pertukarannya sedikit, sehingga proses yang terjadi adalah difusi. Pada perubahan warna yang terjadi saat penelitian, karbondioksida dalam suatu perairan tidak lepas dari pengaruh parameter seperti oksigen terlarut, alkalinitas, cahaya, $\mathrm{pH}$ dan sebagainya, semakin tinggi karbondioksida, maka oksigen yang dibutuhkan bertambah. Konsentrasi karbondioksida sangat erat pula hubungannya dengan konsentrasi oksigen terlarut dalam suatu perairan.

Kadar karbondioksida pada sungai Ampenan tergolong tinggi di sebabkan karena sungai Ampenan digunakan oleh masyarakat sekitar untuk segala kegiatan termasuk pembuangan segala jenis limbah secara langsung. Salah satu cara yang bisa dilakukan untuk mengatasi tingginya karbondioksida adalah melakukan aerasi atau melakukan pengaturan sirkulasi air. Sirkulasi air bisa berjalan dengan baik 
dengan cara mengurangi sampah disekitar DAS Ampenan, dan diberikan aturan bagi masyarakat sekitar yang mau membuang limbah ke aliran sungai.

\section{KESEMPULAN}

Penelitian ini menyimpulkan bahwa pada 5 titik sampel pada sungai Ampenan dan satu kontrol yang diambil dari air yang secara fisik tidak mengalami pencemaran. Hasil pengamatan yang dilakukan secara fisik, sungai Ampenan mengalami pencemaran dari segi bau, warna dan suhu. Berdasarkan hasil analisis kadar $\mathrm{CO}_{2}$ diperoleh hasil pada kelima titik sampel adalah 50, 30, 15 dan $10 \mathrm{mg} / \mathrm{l}$. Kadar $\mathrm{CO}_{2}$ pada sungai Ampenan berada dalam kategori tinggi karena kadar $\mathrm{CO}_{2}$ yang dibolehkan untuk perairan berkisar antara 5-10 $\mathrm{mg} / \mathrm{l}$. Salah satu cara yang bisa dilakukan untuk mengatasi tingginya karbondioksida adalah melakukan aerasi atau melakukan pengaturan sirkulasi air dan diterapkan sanksi bagi masyarakat sekitar yang mau membuang limbah ke aliran sungai.

\section{DAFTAR PUSTAKA}

[1] Samudro, S., Agustiningsih, D., \& Sasongko, S. B. (2012). Analisis Kualitas Air dan Strategi Pengendalian Pencemaran Air Sungai Blukar Kabupaten Kendal. Jurnal Presipitasi: Media Komunikasi dan Pengembangan Teknik Lingkungan, 9(2), 64-71.

[2] Said, I., Jalaluddin, M. N., Upe, A., \& Wahab, A. W. (2012). Penetapan konsentrasi logam berat krom dan timbal dalam sedimen estuaria Sungai Matangpondo Palu. CHEMICA, 10(2), 4047.

[3] Harahap, A., \& Santi, D. N. (2013). Analisis Kualitas Air Sungai Akibat Pencemaran Tempat Pembuangan Akhir Sampah Batu Bola dan Karakteristik Sertakeluhan Kesehatan Pengguna Air Sungai Batang Ayumi di Kota Padangsidimpuan Tahun 2012. Lingkungan dan Keselamatan Kerja, 2(2).

[4] Mahyudin, M., Soemarno, S., \& Prayogo, T. B. (2015). Analisis Kualitas Air Dan Strategi Pengendalian Pencemaran Air Sungai Metro di Kota Kepanjen Kabupaten Malang. Indonesian Journal of Environment and Sustainable Development, 6(2).

[5] Kusumaningtyas, D. I., \& Purnama, P. (2017). Analisa Kadar Fosfat (P-Po4) Di Perairan Sungai Citarum Dan Anak Sungainya Dengan Metode Asam Askorbat. Buletin Teknik Litkayasa Sumber Daya dan Penangkapan, 15(1), 23-29.
[6] Pitayati, P. A., \& Dahlan, M. H. (2017). Analisis Kualitas Air Sungai dan Air Limbah (Outlet) Perusahaan dengan Metode Indeks Pencemaran dan Pengaruhnya terhadap Populasi dan Jenis Ikan. Jurnal Penelitian Sains, 19(2).

[7] Rahmaningsih, S. (2018). Hama \& Penyakit Ikan. Deepublish.

[8] Effendi, H.2003. Telaah Kualitas Air Bagi Pengelolaan Sumber Daya dan Lingkungan Peraiaran. Penerbit: Kanisius. Yogyakarta.

[9] Barus, T. A. (2004). Pengantar limnologi studi tentang ekosistem air daratan. Universitas Sumatera Utara Press. Medan.

[10] Octasari, Z., Hasnunidah, N., \& Marpaung, R. R. T. (2018). Pengembangan Buku Penuntun Praktikum Pencemaran Lingkungan dengan Model ArgumentDriven Inquiry (ADI). Jurnal Bioterdidik: Wahana Ekspresi Ilmiah, 6(1).

[11] Tresna, S. (1991). Pencemaran lingkungan. cetakan pertama, Penerbit PT. Rineka Cipta, Jakarta.

[12] Hidayah, S. N., Widyorini, N., \& Purnomo, P. W. (2017). Analisis Kesuburan Perairan Waduk Jatibarang Berdasarkan Distribusi Dan Kelimpahan Bakteri Heterotrofik. Management of Aquatic Resources Journal, 5(4), 443-452.

[13] Agustiari, A. M., Saputra, S. W., \& Solichin, A. (2018). Beberapa Aspek Biologi Ikan Swanggi (Priacanthus Tayenus) Yang Didaratkan Di Ppp Tawang Kabupaten Kendal. Management of Aquatic Resources Journal, 6(1), 33-42.

[14] Nurhayati, A., \& Herawati, T. (2018). Analisis Faktor Adopsi Inovasi Perikanan Budidaya Karamba Jaring Apung di Waduk Cirata Analysis of Innovation Adoption Factors of Floating Net Cage Aquaculture in Cirata Reservoir. Jurnal Penyuluhan, 14(2).

[15] Al Idrus, S. W. (2015). Analisis pencemaran air menggunakan metode sederhana pada Sungai Jangkuk, Kekalik dan Sekarbela Kota Mataram. Jurnal Pijar Mipa, 10(2).

[16] Al Idrus, S. W. (2013). Pencemaran Udara Akibat Pengolahan Batu Kapur Di Dusun Open Desa Mangkung Praya Barat. Jurnal Pijar Mipa, 8(2).

[17] Fatmalia, E. (2018). Analisis Cacing Sutera (Tubifex Tubifex) Sebagai Bioindikator Pencemaran Air Sungai Gorong Lombok Tengah. Jurnal Pijar Mipa, 13(2), 132-136. 